\title{
232.000 boringer på nettet - gigantisk boringsarkiv tilgaengeligt for alle
}

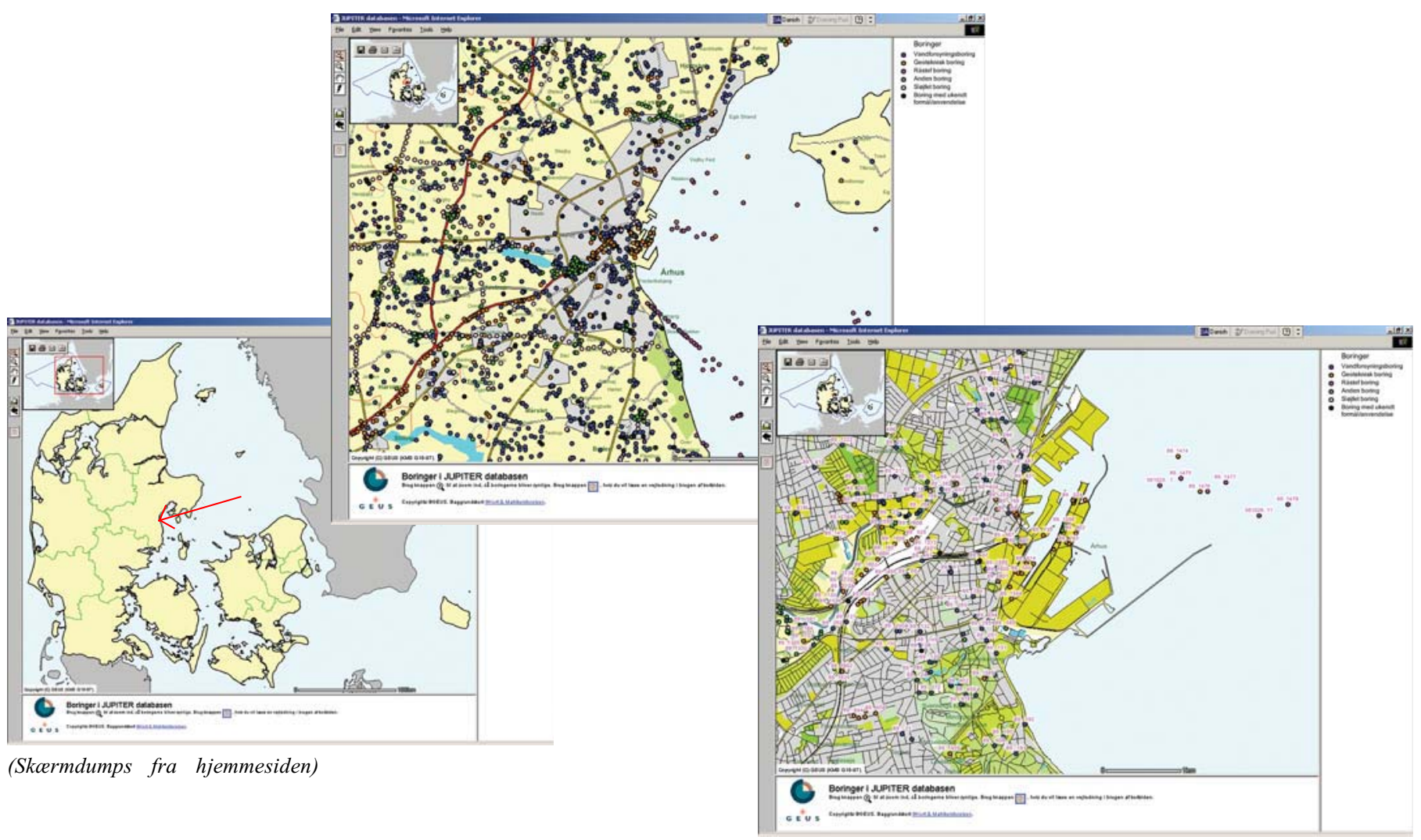

Af informationschef Henrik Højmark Thomsen, GEUS

\section{GEUS (Danmarks og Grønlands} Geologiske Undersøgelse) har åbnet et nyt afsnit på sin hjemmeside (www.geus.dk), hvor man med nogle få klik med musen kan hente oplysninger frem på skærmen om 232.000 boringer i Danmark.

Oplysningerne findes i borearkivet ved Danmarks og Grønlands Geologiske Undersøgelse (GEUS). Her er der siden 1926 arkiveret geologiske oplysninger fra over 270.000 huller, der er boret i de øverste 5250 meter af Danmarks overflade.

"Vi ligger inde med en kolossal stor viden om Danmarks geologi, og med åbningen af den nye netfacilitet bliver det lettere for danskerne selv at hente denne viden," siger Jørgen Tulstrup, som leder Geologisk Datacenter ved GEUS.

Direkte link til boringer på nettet: http://www.geus.dk/jupiter/index-dk.htm
Oplysninger om geologi og grundvand De mange huller er hovedsageligt boret for at finde vand, men også for at undersøge bæreevnen af jordlagene i forbindelse med byggeri samt søgen efter råstoffer og forureninger. Borearkivet har i årenes løb været en vigtig kilde til oplysninger om Danmarks geologi og grundvand. Den store mængde geologiske data er således blevet flittigt brugt i den hydrogeologiske kortlægning af landet i 1970erne og større miljøforskningsprojekter som fx Lossepladsundersøgelserne i 1980erne samt Det Strategiske Miljøforskningsprogram i 1990erne. I dag indgår arkivets data blandt andet i det store arbejde med zonering og detailkortlægning af grundvandsressourcen.

"Det er nok de professionelle brugere som brøndborere og folk i amterne og ved vandværkerne eller de rådgivende ingeniørfirmaer, der i første omgang vil trække på webstedet, men borgerne kan selvfølgelig også gå ind og få et indtryk af, hvordan geologien er i nærheden af, hvor de bor," vurderer Jørgen Tulstrup.

"Tidligere skulle folk ringe ind til GEUS' konsulenttjeneste for at få at vide, hvordan geologien er i et område, eller også kunne de købe et udtræk af databasen. Det kan de stadigvæk, hvis de vil have geologisk vejledning, men folk har nu også muligheden for selv at snuse rundt i de mange data," forsætter han.

\section{Borearkivet}

Borearkivet er et resultat af en forudseende lovgivning. Af den første vandforsyningslov fra 1926 fremgår det, at oplysninger om alle vandforsyningsboringer skal indberettes til GEUS. Og siden 1978 har der ifølge Råstofloven også været indberetningspligt for råstofboringer. Mange forskellige mennesker har derfor indsendt oplysninger til GEUS $\mathrm{i}$ årenes løb, og brøndborere, amterne, vandværkerne, rådgivningsfirmaer og ejere af råstofgrave har alle været vigtige bidragydere til opbygning af borearkivet.

Boringerne på nettet kan søges frem på skærmen efter forskellige kriterier, som fx i hvilket amt eller i hvilken kommune der ønskes oplysninger fra, og der er muligheder for at få søgeresultaterne leveret som lister over boringer eller på kort, hvor boringerne er markeret.

Boreoplysningerne, som trækkes direkte fra GEUS' elektroniske boringsdatabase, omfatter beskrivelser af geologien samt administrative og tekniske oplysninger, som for eksempel grundvandspumpning og placeringen af filtre. 